\title{
Sosialisasi Pencegahan COVID-19 Melalui Brosur di RT 20/RW 07 Kelurahan Fatufeto Kota Kupang
}

\author{
Arman Rifat Lette \\ Universitas Citra Bangsa, \\ Jln. Manafe No.17, Kelurahan Kayu Putih, Kota Kupang \\ Email: lette.arman@gmail.com
}

\begin{abstract}
ABSTRAK
Infeksi Coronavirus tipe baru menyebabkan gangguan/penyakit pernapasan yang berat dan fatal serta mirip dengan sindrom gangguan pernapasan akut. Masyarakat perlu berperan secara aktif dalam melakukan upaya pencegahan penularan COVID-19. Tujuan pengabdian masyarakat adalah untuk meningkatkan pengetahuan dan kesadaran masyarakat dalam melakukan upaya pencegahan COVID-19. Metode pengabdian yang dilakukan adalah Sosialisasi kesehatan tentang pencegahan COVID-19 menggunakan brosur dengan cara mendatangi rumah masyarakat untuk sosialiasi dan membagi brosur. Kegiatan pengabdian masyarakat ini dilaksanakan pada hari Rabu-Kamis tanggal 01-02 April 2020 pukul 10.20-12.00 WITA. Kegiatan sosialisasi ini dilaksanakan di wilayah RT 20, Kelurahan Fatufeto, Kota Kupang. Total peserta sebanyak 37 Kepala Keluarga. Selain itu, penulis juga melakukan koordinasi dengan ketua RT 20 dan Pihak gereja. Sosialisasi dapat berjalan dengan baik. Masyarakat begitu senang dan ada beberapa kepala keluarga yang bertanya lebih mendetail terkait upaya pencegahan COVID-19. Masyarakat mulai sadar tentang bahaya dan upaya pencegahan COVID-19. Terbukti dari masyarakat kebanyakan memilih untuk tidak berpergian keluar rumah jika tidak ada kepentingan yang mendesak selama masa pandemic COVID-19. Upaya-upaya pencegahan atau Protokol Kesehatan harus tetap diperhatikan dan dilakukan oleh masyarakat.
\end{abstract}

Kata kunci: COVID-19; Sosilisasi; Pencegahan; Brosur

\begin{abstract}
A new type of Coronavirus infection causes severe and fatal respiratory illnesses and is similar to acute respiratory distress syndrome. The community needs to play an active role in making efforts to prevent the transmission of COVID-19. The aim of community service is to increase public knowledge and awareness in making efforts to prevent COVID-19. The service method carried out is health socialization about the prevention of COVID-19 using brochures by visiting community homes for socialization and distributing brochures. This community service activity is held on Wednesday-Thursday April 01-02 2020 at 10.20-12.00 WITA. This socialization activity was carried out in the RT 20 area, Fatufeto Village, Kupang City. The total number of participants was 37 households. In addition, the authors also coordinated with the head of RT 20 and the church. Socialization works well. The community was very happy and there were several family heads who asked for more details regarding efforts to prevent COVID-19. The public is becoming aware of the dangers and efforts to prevent COVID-19. It is evident that the majority of people choose not to go out of the house if there is no urgent need during the COVID-19 pandemic. Prevention efforts or Health Protocols must still be considered and carried out by the community.
\end{abstract}

Keywords: COVID-19; Socialization Preventif; Brochure 


\section{PENDAHULUAN}

Infeksi Coronavirus (2019-nCoV) menyebabkan gangguan/penyakit pernapasan yang berat dan fatal serta mirip dengan sindrom gangguan pernapasan akut (Chen $\mathrm{N}$, 2020). Coronavirus menyebabkan angka kematian/ mortalitas yang tinggi (Huang, 2020). Gejala-gejala COVID-19 yang paling umum adalah pilek, demam dan batuk kering. Gejala-gejala yang dialami biasanya bersifat ringan dan muncul secara bertahap bahkan beberapa orang yang terinfeksi tidak menunjukkan gejala sama sekali namun sudah dapat menularkan kepada orang lain. Orang-orang lanjut usia (lansia) dan orang-orang dengan kondisi medis yang sudah ada sebelumnya seperti tekanan darah tinggi, gangguan jantung atau diabetes, lebih beresiko terkena COVID-19 (World Health Organization, 2020b).

Data dari World Health Organization (WHO) per tanggal 14 Juli 2020 menunjukkan bahwa jumlah kasus positif COVID-19 yang terkonfirmasi di dunia telah mencapai 12.929.306 kasus, Jumlah Kematian mencapai 569.738 jiwa dan jumlah negara yang telah terinfeksi oleh virus ini mencapai 216 negara(World Health Organization, 2020a). Sementara itu, di Indonesia data per tanggal 14 Juli 2020 menunjukkan jumlah kasus positif yang terkonfirmasi mencapai 78.572 kasus, Sembuh 37.636 orang dan Meninggal mencapai 3.710 orang. Provinsi Nusa Tenggara Timur (NTT) Jumlah kasus positif COVID-19 berdasarkan data per 14 Juli 2020, telah mencapai 121 kasus dan pada bulan Agustus telah mencapai 165 orang (Covid-19, 2020). Penyebaran COVID-19 di Kota Kupang berdasarkan data per Oktober 2020 jumlah kasus Positif COVID-19 mencapai 86 orang, yang sedang dalam perawatan medis sebanyak 33 orang dan sembuh sebanyak 49 orang serta kematian sebanyak 4 orang (Kompas, 2020). Sementara itu, data terbaru diketahui ada 1 kasus positif COVID-19 di wilayah Fatufeto. Sejauh ini, wilayah NTT khususnya Kota Kupang juga telah terjadi transmisi lokal atau penularan virus yang terjadi diantara masyarakat.

COVID-19 dapat menyebar dari orang ke orang melalui percikan-percikan dari hidung atau mulut yang biasa disebut droplet. Droplet dapat menyebar keluar saat orang yang terjangkit COVID-19 batuk atau mengeluarkan napas. Droplet kemudian jatuh dan menempel dipermukaan benda di sekitar seperti: meja, pintu, kursi, kaca dan sebagainya. Jika Orang sehat menyentuh benda atau permukaan tersebut, lalu menyentuh mata, hidung atau mulutnya, maka orang tersebut dapat terjangkit COVID-19. Penularan COVID-19 juga dapat terjadi jika orang secara tidak sadar menghirup percikan yang keluar dari batuk atau napas orang yang terjangkit COVID-19 (UNICEF, 2020). Saat ini, pasien COVID-19 
dan penderita tanpa gejala adalah sumber utama penularan di dalam masyarakat (Hoehl, Rabenau, \& Berger, 2020).

Berbagai upaya pencegahan telah ditetapkan dan dihimbau oleh pemerintah untuk menekan laju penularan coronavirus, seperti : pemakaian masker, cuci tangan secara rutin, Jaga jarak/ physical distancing, etika batuk dan sebagainya. Salah satu Kebijakan, yaitu Pembatasan jarak atau yang biasa disebut physical distancing sejauh ini terbukti efektif dalam mencegah dan menghambat penyebaran virus Corona. Himbauan pencegahan berupa protokol-protokol kesehatan harus dilaksanakan dengan disiplin oleh masyarakat untuk memutus mata rantai penularan. Kedisiplinan masyarakat melakukan protokol kesehatan menjadi sangat penting dalam mencegah penularan COVID-19.

Kurangnya pengetahuan dan kesadaran masyarakat tentang pencegahan COVID-19 akan mempengaruhi perilaku pencegahan di dalam masyarakat. Oleh karena itu perlu dilakukan Komunikasi, Informasi dan Edukasi secara terus-menerus dengan metode dan media yang ada. Salah satu metode KIE adalah dengan sosilisasi. sosialisasi bertujuan untuk memberikan edukasi kepada masyarakat tentang sesuatu hal. Proses sosialisasi yang dialami seseorang mulai dari menerima informasi, memahami dan mempraktekkan segala hal itu gunanya adalah untuk memperoleh pengetahuan dan keterampilan agar dapat berinteraksi dan beraptasi dengan baik dengan kelompok masyarakat tersebut (Abdullah \& Nasionalita, 2018). Pada perkembangannya, sosialisasi menjadi salah satu faktor yang mempengaruhi pengetahuan seseorang.

\section{METODE}

Metode pengabdian yang dilakukan adalah Sosialisasi kesehatan tentang pencegahan COVID-19 menggunakan brosur dengan cara mendatangi rumah masyarakat untuk sosialiasi dan membagi brosur. Selain itu, penulis juga melakukan koordinasi dengan ketua RT 20 dan Pihak gereja untuk mendukung kegiatan pengabdian masyartakat ini. Brosur yang dibagikan merupakan brosur yang dibuat dan dicetak oleh kampus Universitas Citra Bangsa. Brosur berisi pesan-pesan pencegahan COVID-19, meliputi: memakai masker saat keluar rumah, jaga jarak dan menghindari kerumunan, cuci tangan sesering mungkin, etika batuk, membuka jendela rumah dan rutin membersihkan rumah. Kegiatan pengabdian masyarakat ini dilaksanakan pada hari Rabu-Kamis tanggal 01-02 April 2020 pukul 10.20-12.00 WITA. Kegiatan sosialisasi ini dilaksanakan di wilayah RT 20/RW 07, Kelurahan Fatufeto, Kota Kupang -Nusa Tenggara Timur. Selain mengunjungi rumah masyarakat, Penulis juga menempelkan brosur di papan informasi gereja Imanuel 
Batukadera. Peserta kegiatan sosialisasi kesehatan ini adalah Kepala dan anggota keluarga di wilayah RT 20, Kelurahan Fatufeto, Kota Kupang. Total peserta sebanyak 37 Kepala Keluarga.

\section{HASIL, PEMBAHASAN, DAN DAMPAK}

Brosur adalah sebuah media/alat untuk dapat mempromosikan barang, jasa dan lain sebagainya, terbuat dari sebuah kertas yang ada di dalamnya akan memiliki sejumlah informasi serta penawaran tentang jasa ataupun produk tersebut. Brosur juga telah digunakan sebagai media promosi Kesehatan. Dalam media promosi, pesan dimaksudkan untuk mempengaruhi orang lain, atau pesan itu untuk menghimbau khalayak sasaran agar mereka menerima dan melaksanakan gagasan yang kita sampaikan(Notoadmodjo, 2012).

Sosialisasi pencegahan COVID-19 dapat berjalan dengan baik. Masyarakat begitu senang dan ada beberapa kepala keluarga yang bertanya lebih mendetail terkait upaya pencegahan COVID-19. Pertanyaan yang diberikan oleh masyarakat adalah: Apakah benar COVID-19 menyebar melalui udara? Kenapa masyarakat disuruh untuk memakai masker dan menjaga jarak?. Penulis berusaha menjelaskan dengan baik dan terus menghimbau masyarakat agar patuh dalam melakukan upaya pencegahan COVID-19.

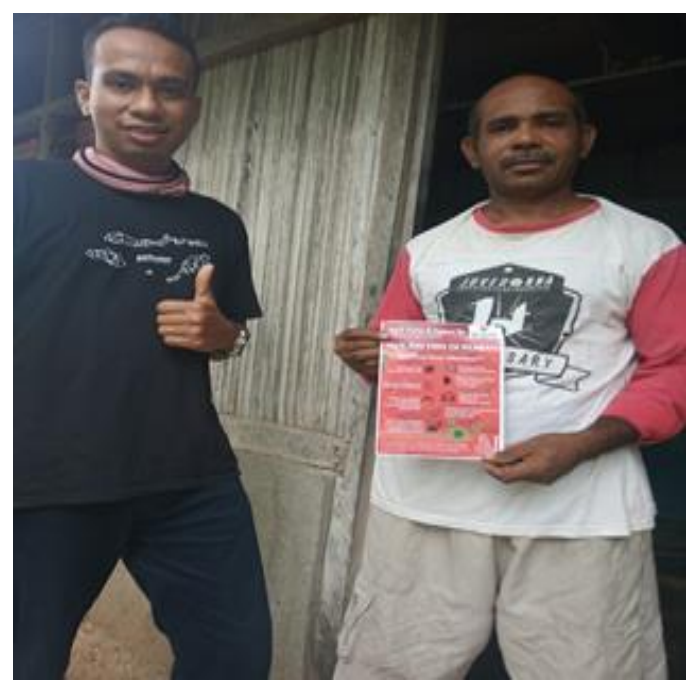

Gambar 1. Bersama salah seorang Kepala Keluarga yang telah menerima brosur

Selain mendatangi rumah masyarakat, Penulis juga meminta ijin kepada pihak gereja Imanuel Batukadera dalam hal ini Ketua Majelis Jemaat untuk menempelkan brosur di papan pengumuman gereja dan membagikan brosur kepada Majelis gereja. Pihak gereja menyetujui dan memberikan ijin sehingga brosur dapat ditempel di papan informasi gereja dan dapat dilihat oleh jemaat yang datang beribadah. 


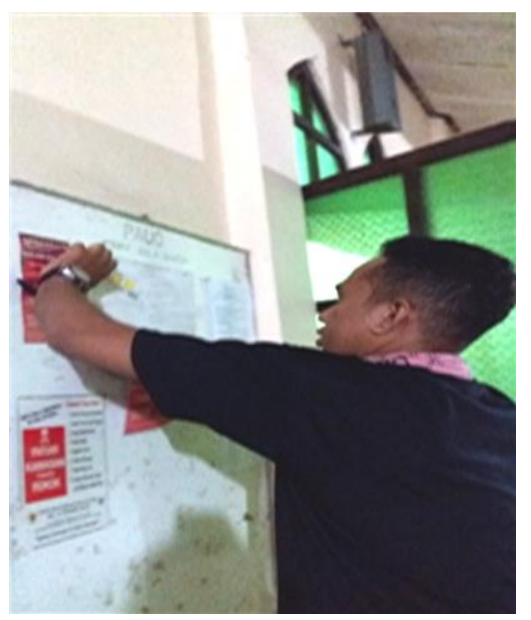

Gambar 2. Penempelan Brosur di papan informasi gereja

Selain itu, penulis juga melakukan koordinasi dengan ketua RT 20 agar brosur dapat dibagikan kepada KK yang belum sempat ditemui dan juga dapat ditempelkan di tempattempat umum lainnya (Kios masyarakat, tiang listrik) yang ada di wilayah RT 20. Ketua RT 20 menerima dengan baik dan mendukung kegiatan pengabdian yang dilaksanakan. Ketua RT 20 mengungkapkan rasa terima kasihnya karena kegiatan pengabdian masyarakat ini. "Kami sebagai orang awam tidak tahu tentang COVID-19 dan cara pencegahannya, sehingga lewat brosur yang dibagikan dapat membuka wawasan masyarakat. Harapannya masyarakat dapat sadar dan aktif melakukan pencegahan”. Kata ketua RT 20.

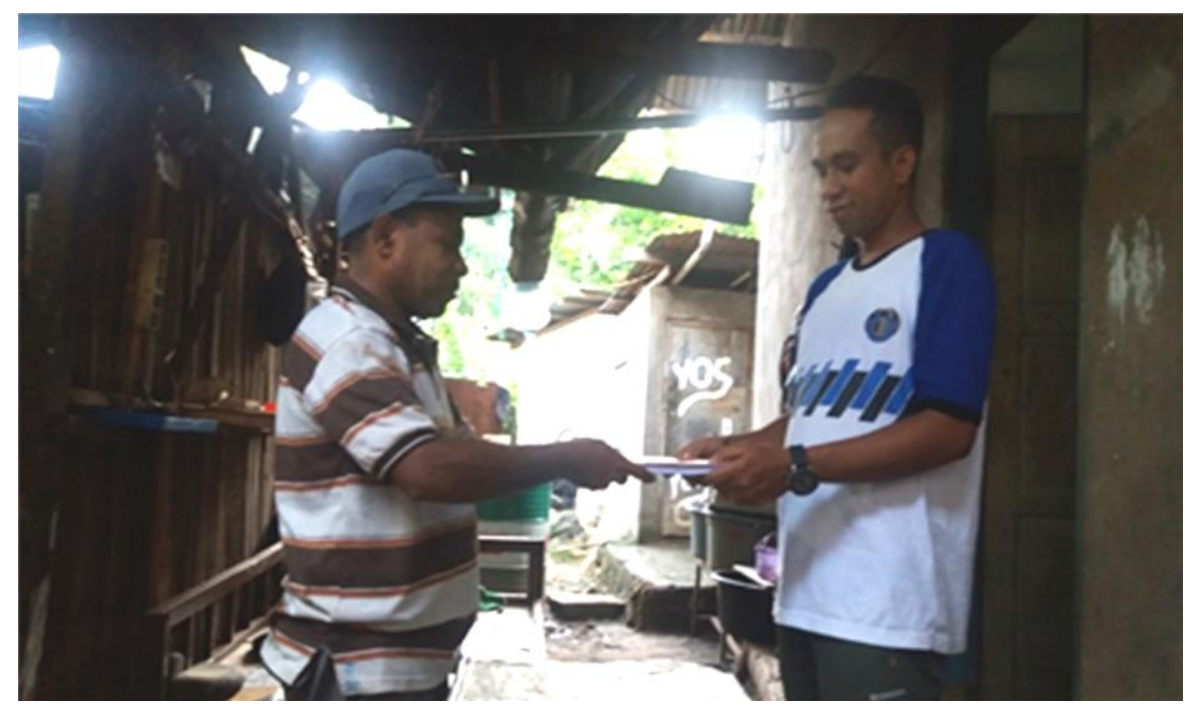

Gambar 3. Pemberian Brosur kepada Ketua RT 20 untuk dapat dibagikan dan ditempel di tempat-tempat umum

Berdasarkan pengamatan setelah dilakukannya sosialisasi masyarakat mulai tahu dan sadar tentang bahaya dan upaya pencegahan COVID-19. Pencegahan yang menjolok terlihat adalah Physical Dstancing. Berbagai upaya pencegahan telah ditetapkan dan 
dihimbau oleh pemerintah untuk menekan laju penularan coronavirus, seperti: pemakaian masker, cuci tangan secara rutin, Jaga jarak/Social Distancing, etika batuk dan sebagainya. Salah satu Kebijakan, yaitu Social Distancing sejauh ini sangat efektif dalam menghambat penyebaran virus/penyakit, yakni dengan mencegah orang sakit melakukan kontak dekat dengan orang lain untuk mencegah penularan COVID-19. Istilah social distancing kemudian mengalami perubahan menjadi physical distancing (Palilingan, 2020)

Masyarakat RT 20 lebih memilih untuk tidak berpergian keluar rumah jika tidak ada kepentingan yang mendesak. Masyarakat RT 20 lebih memilih di dalam rumah dan menghindari tempat-tempat keramaian seperti toko, pasar dan tempat umum lainnya sebagai salah satu upaya pencegahan COVID-19. Selain itu masyarakat juga mulai memahami pentingnya mencuci tangan terbukti masyarakat menyiapkan tempat cuci tangan dan sabun di depan rumah mereka.

\section{SIMPULAN}

Kegiatan sosialisasi pencegahan COVID-19 dapat berjalan dengan baik dan terjadi peningkatan pengetahuan masyarakat tentang cara pencegahan COVID-19. Masyarakat menerima kedatangan penulis dan berterima kasih atas brosur yang telah diberikan. Masyarakat juga antusias dalam bertanya jika ada hal-hal yang kurang dimengerti berkaitan dengan upaya pencegahan COVID-19. Saran dari Penulis adalah selama masa Pandemi COVID-19 Protokol Kesehatan harus tetap diperhatikan dalam melakukan kegiatan pengabdian masyarakat. Perlu juga memperhatikan waktu pelaksanaan, disarankan pada sore hari dimana masyarakat sudah pulang bekerja dan dapat bertemu dengan kepala keluarga

\section{UCAPAN TERIMAKASIH}

Penulis mengucapkan terima kasih kepada Universitas Citra Bangsa yang telah mendukung terlaksananya kegiatan pengabdian masyarakat ini.dengan cara memberikan ijin dan menyumbangkan brosur. Penulis juga mengucapkan terima kasih kepada Ketua RT 20 dan ketua Majelis Jemaat Imanuel Batukadera yang telah memberikan ijin dan mendukung kegiatan pengabdian ini. 


\section{DAFTAR PUSTAKA}

Abdullah, N. N., \& Nasionalita, K. (2018). Pengaruh sosialisasi terhadap pengetahuan pelajar mengenai hoax (Studi Pada Program Diseminasi Informasi Melalui Media Jukrak Di SMKN 1 Pangandaran). CHANNEL: Jurnal Komunikasi, 6(1), 120-130. https://doi.org/10.12928/channel.v6i1.10217

Chen N, et al. (2020). Epidemiological and clinical characteristics of 99 cases of 2019 novel coronavirus pneumonia in Wuhan, China: a descriptive study. Www.Thelancet.Com, 395, 507-513.

Covid-19, G. T. (2020). Situasi virus COVID-19 di Indonesia. Gugus Tugas Percepatan Penanganan Covid-19. https://covid19.go.id/

Hoehl S, Rabenau H, Berger A, et al. (2020). Evidence of SARS-CoV-2 Infection in Returning Travelers from Wuhan, China. N Engl J Med, 382(13), 1278- 1280. https://doi.org/10.1056/NEJMc2001899

Huang, et al. (2020). Clinical features of patients infected with 2019 novel coronavirus in Wuhan, China. Www.Thelancet.Com, 395, 497-506.

Kompas. (2020). Klaster Baru Penularan Corona di Kota Kupang Muncul dari Karyawan Bank. Kompas.Com. https://kupang.kompas.com/read/2020/10/01/23414901/klasterbaru-penularan-corona-di-kota-kupang-muncul-dari-karyawan-bank

Notoadmodjo. (2012). Promosi Kesehatan dan Perilaku Kesehatan. In PT Rineka Cipta.

Palilingan, T. (2020). Aspek hukum dalam dalam penanganan wabah covid-19. http://manadopost.id/read/2020/04/20/ASPEK-HUKUM-DALAM-DALAMPENANGANAN-WABAH-COVID-19/67536

UNICEF. (2020). Pesan dan Kegiatan Utama Pencegahan dan Pengendalian COVID-19 di Sekolah. UNICEF. https: // www.who.int/ docs/defaultsource/searo/indonesia/covid19/pesan-dan-kegiatan-utama- pencegahan-danpengendalian- covid- 19- di- sekolah--- indonesian--march-2020.pdf?sfvrsn= 5cdfea17_2

World Health Organization. (2020a). Coronavirus disease (COVID-19) pandemic. In World Health Organization. https://www.who.int/emergencies/diseases/novelcoronavirus-2019

World Health Organization. (2020b). Pertanyaan dan jawaban terkait corona virus. World Health Organization. https://www.who.int/indonesia/news/novel-coronavirus/qa-forpublic 